Slađana Pavić ${ }^{1}$, Marija Antić1, Aleksandra Andrić2 ${ }^{2}$ Milica Jovanović ${ }^{3}$, Aleksandra Pavić ${ }^{4}$, Aleksa Novković ${ }^{4}$

\title{
GOJAZNOST KAO PREDIKTIVNI FAKTOR ZA NASTANAK AKUTNOG RESPIRATORNOG DISTRES SINDROMA KOD BOLESNIKA SA VIRUSOM INFLUENCE A
}

\section{Sažetak:}

Uvod: Gojazne osobe imaju veći rizik za oboljevanje i smrtnost od virusa influence A.

Cilj istraživanja je bio da se ispita klinički tok influence kod gojaznih osoba i uticaj gojaznosti na ishod bolesti i pojavu komplikacije - akutnog respiratornog distres sindroma (ARDS).

Metodi istraživanja: Istraživanje je obuhvatilo bolesnike sa influencom lečene od 01.01.2006. do 31.12.2017. godine u Opštoj bolnici Užice. Virus influence je dokazan na Institutu Torlak, polimeraza lančanom reakcijom i dokazivanjem titra anti IgM antitela. Prikupljani su epidemiološki, klinički, biohemijski i mikrobiološki podaci. Bolesnicima je rađena radiografija pluća. Prisustvo ARDS-a i stepen gojaznosti procenjivani su prema međunarodnim standardima.

Rezultati: Od ukupno 405 bolesnika sa influencom, kod 21 bolesnika se bolest iskomplikovala pojavom ARDS-a. $71.4 \%$ ovih bolesnika imali su virus influence A H1N1. Isti procenat bolesnika bio je stariji od 65 godina. Većina bolesnika sa ARDS-om bila je gojazna (85.7\%) i imala udruženo astmu ili hroničnu opstruktivnu bolest pluća (HOBP) (80.9\%). Bolest se kod $57.1 \%$ bolesnika završila smrtnim ishodom, od čega je $75 \%$ osoba bilo gojazno. Gojaznost je kod $66.7 \%$ ovih bolesnika bila tipa II.

Zaključak: Kod bolesnika sa teškom kliničkom formom influence A i pojavom ARDS-a najčešći je podtip H1N1 influenca A virusa. Značajan broj bolesnika je stariji od 65 godina sa udruženom astmom/HOBP. Gojaznost je najvažniji faktor rizika za nastanak ARDS-a i smrtni ishod ovih bolesnika.

Ključne reči: gojaznost, akutni respiratorni distres sindrom, virus influence A H1N1

1 Slađana Pavić, Odeljenje za infektivne i tropske bolesti Opšte bolnice Užice, Užice, Srbija. sladjanapj@gmail.com

2 Institut za javno zdravlje, Užice, Srbija.

3 Institut za infektivne i tropske bolesti, Beograd, Srbija.

4 Medicinski fakultet Univerziteta u Beogradu, Beograd, Srbija. 


\begin{abstract}
:
Introduction: Obese people have a higher risk of morbidity and mortality from influenca A virus.

The aim of the study was to examine the clinical course of influenca in obese people and the effect of obesity on the outcome of the disease and the occurrence of acute respiratory distress syndrome (ARDS).

Methods: We investigated patients with influenca, treated from 01.01.2006. until 31.12.2017. in the General Hospital Uzice. influenca virus has been diagnosted at the Institute for immunology and virusology „Torlak“ in Belgrade, by polimerasa chain reaction. We collected epidemiological, clinical, biochemical and microbiological data. Patients were given an X-ray of the lungs. ARDS and the degree of obesity were assessed according to international standards.

Results: Out of a total of 405 patients with influenca, in 21 patients, the disease was complicated by ARDS. $71.4 \%$ of these patients had influenca A virus H1N1. The same percentage of patients was older than 65 years. Most patients with ARDS were obese (85.7\%) and had associated asthma or chronic obstructive pulmonary disease (HOPD) (80.9\%). The illness ended with fatal in $57.1 \%$ patients $75 \%$ of them were obese. In $66.7 \%$ of these patients obesity was type II.

Conclusion: In patients with severe clinical form of influenca A and ARDS, the subtype of H1N1 influenca A virus was the most common. A significant number of patients was older then 65 years with associated asthma/COPD. Obesity is the most important risk factor for ARDS and the fatal outcome of these patients.
\end{abstract}

Key words: obesity, acute respiratory distress syndrome, influenca A virus H1N1

\title{
Uvod
}

Virus influence A može uzrokovati akutnu, rapidno progresivnu respiratornu bolest, akutni respiratorni distres sindrom (ARDS) i smrtni ishod (1).

Posebno tokom pandemične infekcije virusom A, podtip H1N1, 2009. godine, autori su prikazali značajan broj bolesnika sa teškom kliničkom slikom i neophodnim lečenjem u jedinicama intenzivne nege (2-5). Tešku formu bolesti najčešće su imali stariji bolesnici sa komorbiditetima (6).

Važan faktor rizika za nastanak smrtnog ishoda kod bolesnika sa influencom A H1N1 bila je i izrazita gojaznost (7).

Cilj ispitivanja

Cilj našeg rada bio je da se ispita uticaj gojaznosti na klinički tok i pojavu ARDS-a i na konačni ishod bolesti kod bolesnika sa influencom A. 


\section{Metodi}

Istraživanje je obuhvatilo bolesnike lečene na Odeljenju za infektivne bolesti jedinici za intenzivnu negu Opšte bolnice Užice, u periodu od 01.01.2006. do 31.12.2017. godine.

Virus influence A dokazivan je na Institutu za imunologiju i virusologiju „Torlak“ u Beogradu iz brisa ždrela reakcijom umnožavanja polimeraze (PCR) i određivanjem IgM titra antitela iz seruma.

Kriterijumi za dijagnozu ARDS-a bili su:

- akutno kliničko stanje,

- klinička slika respiratonog oštećenja (tahipneja > 20 min),

$-\mathrm{Pa} 02<6,6 \mathrm{kPa}(50 \mathrm{mmHg})$,

- bilateralni plućni infiltrati na rendgenogramu (8).

Klasifikacija stepena gojaznosti vršena je prema vrednosti indeksa telesne mase (body mass index, BMI), pri čemu vrednost BMI 30 do $34.9 \mathrm{~kg} / \mathrm{m}^{2}$ označava I stepen gojaznosti, 35 do $39.9 \mathrm{~kg} / \mathrm{m}^{2}$ sten II, a BMI $\geq 40 \mathrm{~kg} / \mathrm{m}^{2}$ III stepen gojaznosti (9).

Analizirani su sledeći podaci:

- epidemiološki: uzrast, pol;

- komorbiditeti: diabetes mellitus, astma, hronična opstruktivna bolest pluća (HOBP), neurološke i kardiološke bolesti;

- laboratorijske analize: hematološke, biohemijske, mikrobiološke;

- radiografija pluća.

\section{Rezultati}

Ispitano je ukupno 405 bolesnika sa influencom A. Među njima, 42 (10.4\%) bolesnika su imali tešku formu bolesti sa kliničkim i radiografskim znacima masivne bronhopneumonije, od kojih je kod 21 (50\%) bolesnika nastao ARDS.

Virus influence top A, podtip H1N1 izolovan je kod 15 (71.4\%) bolesnika sa influencom i ARDS-om.

Epidemiološki, klinički i laboratorijski rezultati ispitanika prikazani su u tabeli 1.

Tabela 1. Epidemiološki podaci i komorbiditeti bolesnika sa influencom i ARDS-om

\begin{tabular}{|l|c|c|}
\hline Karakteristike & Broj bolesnika (\%)/ N=21 & $\mathrm{p}$ \\
\hline Uzrast $\geq 65$ godina & $15(71.4)$ & 0.025 \\
\hline Pol (muški) & $13(61.9)$ & 0.482 \\
\hline Komorbiditeti & $18(85.7)$ & $<0.001$ \\
\hline Gojaznost &
\end{tabular}




\begin{tabular}{|l|c|c|}
\hline Karakteristike & Broj bolesnika (\%)/ N=21 & $\mathrm{p}$ \\
\hline Diabetes mellitus & $12(57.1)$ & 0.807 \\
\hline Karakteristike & Broj bolesnika (\%)/ N=21 & $\mathrm{p}$ \\
\hline Kardiološke bolesti & $9(42.9)$ & 0.376 \\
\hline Astma/HOBP & $17(80.9)$ & 0.001 \\
\hline Neurološki poremećaji & $6(28.5)$ & 0.029 \\
\hline Bakterijski izolati (sputum, aspirat i bris tubusa) & $14(66.7)$ & 0.494 \\
\hline Leukocitoza $>15 \times 10^{9} / \mathrm{L}$ & $13(61.9)$ & 0.462 \\
\hline C reaktivni protein $>5 \mathrm{mg} / 1$ & $18(85.7)$ & 0.001 \\
\hline
\end{tabular}

p - statistička značajnost između broja bolesnika sa navedenim parametrom u odnosu na ukupan broj ispitanika sa ARDS-om.

Bolesnici sa ARDS-om bili su u značajnom broju stariji od 65 godina, gojazni i imali astmu/HOBP.

U tabeli 2 prikazani su rezultati univarijantne linearne regresije parametara uzrast, gojaznost i astma/HOBP u odnosu na nastanak ARDS-a.

Tabela 2. Uzrast bolesnika i komorbiditeti kao prediktori nastanka ARDS-a

\begin{tabular}{|l|c|c|c|}
\hline \multirow{2}{*}{$\begin{array}{l}\text { Uzrast i komorbiditeti (nezavisna } \\
\text { varijabla) }\end{array}$} & \multicolumn{3}{|c|}{ ARDS (zavisna varijabla) } \\
\cline { 2 - 4 } & $\mathrm{B}$ & S.E. & $\mathrm{P}$ \\
\hline Uzrast $\geq 65$ godina & 0.229 & 0.094 & 0.016 \\
\hline Gojaznost & 0.45 & 0.09 & 0.000 \\
\hline Astma/HOBP & 0.307 & 0.101 & $<0.001$ \\
\hline
\end{tabular}

Multivarijantnom analizom je dokazano da je najznačajniji pozitivni prediktivni faktor za nastanak ARDS-a kod bolesnika sa influencom A bila gojaznost.

Gojaznost prvog stepena bila je kod 6 (35.3\%), II stepena kod 7 (41.2\%), III stepena kod 4 (23.5\%) bolesnika.

Bolest se kod 12 (57.1\%) bolesnika završila smrtnim ishodom, Među njima, 9 (75\%) osoba je bilo gojazno. Gojaznost je kod $66.7 \%$ ovih bolesnika bila tipa II.

$\mathrm{U}$ tabeli 3 su prikazani rezultati analize stepena gojaznosti, uzrasta preko 65 godina i prisustva podtipa H1N1 virusa influence A u odnosu na letalni ishod. 
Tabela 3. Uzrast, gojaznost i podtip virusa H1N1 kod bolesnika sa letalnim ishodom

\begin{tabular}{|l|c|c|}
\hline Parametar & Letalni ishod $(\%) / \mathrm{N}=12$ & $\mathrm{p}$ \\
\hline Uzrast $>$ 65 godina & $8(66.7)$ & 0.586 \\
\hline Gojaznost & $9(75)$ & 0.023 \\
\hline Virus influence A podtip H1N1 & $10(83.3)$ & 0.001 \\
\hline
\end{tabular}

p - statistička značajnost između broja bolesnika sa navedenim parametrom u odnosu na ukupan broj ispitanika sa letalnim ishodom.

Nađeno je značajno prisustvo podtipa H1N1 influenca A virusa i gojaznosti kod bolesnika koji su imali smrtni ishod zbog influence komplikovane razvojem ARDS-a.

\section{Diskusija}

Gojaznost je danas jedna od najčešćih bolesti u svetu (9). Ona povećava verovatnoću nastanka mnogih drugih bolesti, kao što su neka srčana oboljenja, šećerna bolest, opstruktivna apneja tokom sna, neke vrste karcinoma, astma (10). Dokazan je uticaj gojaznosti na smanjenje imunološkog odgovora organizma nakon vakcine protiv virusa influence (11).

Analizom sociodemografskih karakteristika naših bolesnika sa influencom A uočili smo značajno veće prisustvo ARDS-a kod osoba starijih od 65 godina. Analiza bolesnika prema polu nije ukazala na značajne razlike. Sličan zaključak su izveli i drugi autori čiji su stariji ispitanici češće imali ARDS, bez značajne razlike u polu (6).

Značajna većina naših bolesnika imala je gojaznost $i$ astmu, odnosno HOBP. Naš rezultat je u skladu sa istraživanjem Louiea i saradnika, gde je gojaznost dokazana kao značajan faktor za nastanak smrtnog ishoda kod bolesnika sa influencom uzrokovanom virusom tipa A H1N1 (7). Većina naših ispitanika imala je podtip H1N1 influenca A virusa, a $75 \%$ bolesnika sa letalnim ishodom bolesti bili su gojazni, pa i te činjenice smatramo podudarnom. Isti autori su ukazali na astmu kao značajnu udruženu bolest (7). Naši rezultati su, takođe, u skladu sa pomenutim istraživanjem.

S obzirom na procenat bakterijskih izolata, naše istraživanje nije pokazalo značajno prisustvo udružene bakterijske bronhopneumonije. Ipak, biohemijski parametri bakterijske infekcije bili su prisutni kod većine ispitanika, pa se može pretpostaviti da je u značajnoj meri bila prisutna i bakterijska superinfekcija. Nedostatak izolata koji bi to dokazali može se objasniti antibiotskom terapijom koju je većina bolesnika dobijala ambulantno, od samog početka bolesti.

I drugi istraživači smatraju da gojazne osobe imaju značajno veći rizik za oboljevanje i smrtnost od virusa influence (12).

Svetska zdravstvena organizacija je ukazala na gojaznost kao nezavisan faktor u nastanku komplikacija kod pojave influence (13). 
Uticaj gojaznosti na pogoršanje kliničke slike influence i pojavu ARDS-a može se objasniti uticajem na celularni imuni odgovor. Za adekvatan imunološki odgovor i odbranu organizma potrebno je da dendritske ćelije prezentuju virus influence $i$ podstaknu aktivaciju influenca-specifičnih CD4+i CD8+ T ćelija. CD4+ ćelije utiču na sintezu i sekreciju citokina, aktivaciju i citotoksične funkcije CD8+ ćelija i sintezu specifičnih antiinfluenca antitela (14).

Pokazano je da gojazne osobe imaju niži nivo CD4+ i CD8+ ćelija, manju ekspresiju CD69 i CD28 receptora koji učestvuju u aktivaciji i proliferaciji T ćelija. Takođe, smanjena je ekspresija CD40 molekula i interakcija sa CD40L na dendritskim ćelijama (11). Na taj način nastaju defekti u funkcionisanju celularnog, a posledično i humoralnog imunog odgovora na virus influence.

\section{Zaključak}

Kod bolesnika sa influencom kod kojih se bolest komplikuje nastankom ARDS-a, najčešći uzročnik influence bio je virus influence A podtip H1N1. Ovaj podtip virusa bio je najžešći i kod bolesnika kod kojih se bolest završila smrtnim ishodom. Bolesnici sa influencom A bili su najčešće uzrasta starijeg od 65 godina. Značajan broj ovih bolesnika imao je astmu ili hroničnu opstruktivnu bolest pluća. Najznačajniji faktor koji je doprineo nastanku ARDS-a bila je gojaznost. Kod bolesnika sa letalnim ishodom bolesti gojaznost je takođe bila značajan faktor za takav ishod bolesti. 